

\title{
LIQUIDITY RISK MANAGEMENT AND FINANCIAL PERFORMANACE OF STATE OWNED ENTERPRISES IN KENYA
}

\author{
1* Emmy Chelangat Rop \\ PhD. Candidate: Department of Accounts and Finance, Kenyatta University \\ *Corresponding Author's E-mail: emmychelangat@yahoo.com \\ ${ }^{2}$ Dr.Ambrose Jagongo \\ Department of Accounts and Finance, Kenyatta University
}

\begin{abstract}
Purpose: The study sought to investigate the effect of liquidity risk management on financial performance of state owned enterprises in Kenya.

Materials and Methods: The study adopted a desktop methodology. Desk research refers to secondary data or that which can be collected without fieldwork. Desk research is basically involved in collecting data from existing resources hence it is often considered a low cost technique as compared to field research, as the main cost is involved in executive's time, telephone charges and directories. Thus, the study relied on already published studies, reports and statistics. This secondary data was easily accessed through the online journals and library

Results: The results revealed that the studies done had conceptual framework gap. The study also found out that the study had geographical gap because they were not conducted in Kenya and also had different time scope

Unique contribution to theory, practice and policy: The study will be significant to state owned enterprises, students, general public and State Corporations Advisory Committee as it will offer contributions from both a theoretical and practical perspective. Regulatory bodies such as SCAC as well as the government can utilize the findings from the study to improve on the framework for policy formulation and regulation. The study also recommends the Commercial and manufacturing state Corporations to adopt efficient strategies to improve financial performance through risk management process.
\end{abstract}

Keywords: Liquidity Risk Management, Financial Performance, State Owned Enterprises 


\subsection{INTRODUCTION}

Kenya has approximately 260 state Corporations which play an important role in the economic and social development of the country by providing essential social services and achieving strategic commercial objectives on behalf of Government and to the benefit of Citizen's. However the financial performance and operational efficiency of many State Corporations have been deteriorating in recent years weighing heavily on the public finances by increasing reliance on budgeting support from the government in the form of grants, subsidies, government loans and debt guarantees. These government transfers to state corporations are no longer proportional to the social and economic benefits gained from these corporations in effect limiting public resources available for investment in other critical areas of national development(The National Treasury and planning, 2021).

The amount of money being absorbed by the State Owned Enterprises (SOEs) from the exchequer far surpasses the tax revenue gained from them. Capital grants to SOEs have increased by almost $120 \%$ in the last four years, rising from Kshs 169 billion in the 2013/14 FY to Kshs 414 billion in 2016/17 and about Kshs 345 billion in 2017/18. This has been a HUGE increase and to put it into perspective this ranges from between 5-6\% of annual GDP just on capital grants. The pressure of SOEs levied on the budget is evident if they are absorbing so much capital but not creating the requisite economic value for a net gain to the country. State owned enterprises take upto 6\% GDP trough capital grants. Often such investments do not bear financial returns leaving a hole in the Budget which is filled by tax payer ((Kenya Business Guide, 2019).

The public sector in many countries today faces a major challenge to adapt to the new global reality of doing more with less or doing less with less. At the same time risk management has developed into a dominant concept of vital importance for the survival of public organizations as a new methodology approach to decision making for public officials (Eleftheriadis and Vyattas, 2018).

Liquidity is one of the most important goals of working capital management and central task of revenue optimization and company's financial performance. Efficient working capital management leads to an improvement in the operating performance of the business concern and it helps to meet the short-term liquidity (Maness and Zleflow, 2005; Samiloglu and Demirgunes, 2008). Increased use of overdrafts, lateness in payments of trade creditors, and decreasing cash balances may all signal a weakening liquidity position and a potentially increased probability of default. Current liability coverage ratio, a measure of a firm's liquidity position provides a litmus test for firm's solvency. It is considered the most accurate method as cash used to pay off dividends is subtracted thus giving a truer picture of the operating cash flow. Haczynski (2015) contended that liquidity is essentially a short-term problem caused by short-term unexpected liabilities and the funding requirements of long-term liabilities that have adverse effect on firm financial performance. Liquidity risk therefore arises from the erraticism in short-term assets and liabilities and short-term components of long term assets and liabilities.

According to Podilchuk (2013), financial optimization of a company is usually performed along two basic dimensions: long-term and short-term analysis. The former is aimed at capital structure 
optimization, which is the balance of debt and equity maximizing the value of the firm. Short term optimization focuses on liquidity management. Basically, current assets management is the major tool for capital structure optimization. Therefore, the task of the company's chief financial officer (CFO) is to conduct effective liquidity management to maximize the value of the company and its financial performance. The key factor in identifying firms in liquidity is their inability to meet contractual debt obligations due to poor revenue. This has a negative effect on firms' financial performance (Elloumi and Gueyie, 2001).

As argued by Eljelly (2004), managing liquidity is important when firms are in a good situation, but is most important during troubled times of firms' performance. When a firm is unable to pay its obligations, it is illiquid. Furthermore, aggressive liquidity management is associated with higher corporate value, despite differences in structural characteristics or in the financial system of a firm. Liquidity management is important for all firms in all situations.

Halling and Haydan (2006) explained that an institution should define and identify its liquidity risk. A Company's liquidity needs and the sources of liquidity available to meet those needs depend significantly on the company's business and product mix, balance sheet structure and cash flow profiles of its on- and off-balance sheet obligations. As a result, an institution should evaluate each major on and off-balance sheet position, including the effect of embedded options and other contingent exposures that may affect the institution's sources and uses of funds, and determine how it can affect liquidity risk (Jeanne and Svensson, 2007).

A study conducted in China by Dejin (2020) on liquidity management and profitability in Chinese Big Four state owned commercial banks revealed that the Chinese Big Four state owned Commercial Banks are proved to have significant influence on profitability from five aspects. When profitability is measure by return on assets, return on equity, and DuPont analysis, the coefficients for cash ratio, liquid asset ratio, and capital ratio are verified to be significantly positive with profitability. From the study, it is indicated that increased cash ratio, liquid asset ratio, and capital ratio will increase bank profitability. Nevertheless, coefficients for current ratio, quick ratio, cash conversion cycle, and investment ratio are significantly negative with profitability. This indicates that increasing current ratio, quick ratio, and investment ratio as well as cash conversion cycle will decrease bank profitability accordingly. But the relationship between investment ratio and bank profitability is not significant at one percent level.

A study in India by Wani and Dar (2015) on the relationship between Financial Risk and Financial performance of Indian insurance Industry revealed that $54.7 \%$ changes in financial performance of life insurance companies in India could be accounted for by changes in capital management risk, solvency risk, liquidity risk, underwriting risk, size of the company and volume of capital.

A study in Nigeria by Tesseer et al. (2018) on effect of Liquidity Management on the Financial Performance of Banks in Nigeria established that liquidity ratio (LQR) have positive and significant effect on financial performance of DMB as measured by return on assets (ROA), return on equity (ROE) and net interest margin(NIM).It was recommended that banks in Nigeria should establish sound governance and risk management systems by developing strategies, policies for liquidity management that is well integrated into its risk management practices as well as establish a contingency funding plan to address any liquidity shortfall during periods of 
stress or emergency while ensuring that active monitoring liquidity funding needs to avert any liquidity challenge that could trigger crisis in the banks is promptly addressed.

Muriithi and Waweru (2017) studied Liquidity Risk and Financial Performance of Commercial Banks in Kenya. Liquidity risk was measured by liquidity coverage ratio (LCR) and net stable funding ratio (NSFR) while financial performance by return on equity (ROE). The overall effect was that liquidity risk has a negative effect on financial performance.

Muriungi et al. (2017) who looked at risk management share that in finance, managers must be carefully to consider risk avoidance structure and channels that allay the fear of financial losses. Sometime, the firms must take measures to share or transfer the risks by taking insurance policies or spreading the investment portfolios such that when one sector of the economy is depreciating, the flourishing, and the organization can leverage on them.

Krause and Tse (2016) identified that Firms that use sound risk management practices obtain higher valuations, achieve better financial performance and experience diminished costs of financial distress. Recent empirical evidence provides support for theoretical propositions in the literature that risk management practice increases value and returns. There is therefore need to pre-empt and prepare for them when and if they eventually occur. This is where risk management and financial performance comes in, changing perception about risks being threats to being opportunities to minimize cost.

The corporate world faces a lot of risks and hence for improved financial performance, there is need to have in place sound and effective risk management (Alshatti, 2015). Alshatti (2015) showed that risk management is not applicable in the commercial sector but can apply even in government setting and any other sector of the economy. This is due to the fact, that all organizations need resources for delivery of products and services. The resources are limited in supply and hence the need for proper management to attain set objectives. This is where liquidity risk management comes in.

In addition top managers need to know the regulations and policies that they will be able to perform liquidity risk management in an efficient way. A manager cannot gain financial health by using liquidity risk management alone until he/she is aware of financial regulations and financial policies. The study therefore seeks to investigate the effect of liquidity risk management on financial performance of state owned enterprises.

\subsubsection{Liquidity Risk Management}

Liquidity risk is the risk that a business will have insufficient funds to meet its financial commitments in a timely manner. The two key elements of liquidity risk are short-term cash flow risk and long-term funding risk. The long-term funding risk includes the risk that loans may not be available when the business requires them or that such funds will not be available for the required term or at acceptable cost. All businesses need to manage liquidity risk to ensure that they remain solvent (CPA Australia, 2010).

In order to achieve optimal level of liquidity, the company must pursue strong liquidity management, which in turn requires strict and systematic financial planning of cash. Insufficient liquidity management may cause severe difficulties and losses due to unfavorable short-term developments even for the company with positive long-term prospects (Richards and Laughlin, 
1980). Liquidity risk may be mitigated by careful cash flow management including optimizing working capital and by maintaining unused, committed financing facilities or a liquidity buffer. These allow the business to easily meet its future requirements or contingencies (CPA, Australia 2010). Internal controls are key elements of risk management frameworks. They include processes to assess, mitigate and monitor risks. Organizations can embed internal controls throughout the programme cycle and as part of its overall governance structures and reporting systems.

The annual operating budget forms the basis of the cash flow forecast and the person responsible for monitoring and managing cash must be closely involved in its preparation. Regular cash flow forecasts, when compared to the annual budget, will highlight variances from what was anticipated and prompt corrective action to offset unfavorable trends in availability of cash. Planning should take into account transaction and other associated costs including the effect of tax payments on available funds (CPA, Australia 2010).

According to Francis (2017) Cash Conversion Cycle shows the time lag between expenditure for the purchases of raw materials and the collection of sales of finished goods. CCC is a measure of the efficiency of Working Capital Management as it indicates how quickly the current assets are converting into cash. CCC comprises three components of days inventory outstanding (DIO), days sales outstanding (DSO), and days payables outstanding (DPO);

\section{Cash Conversion Cycle $(\mathrm{CCC})=$ Days Inventory Outstanding (DIO) + [Days Sales Outstanding (DSO) -Days Payables Outstanding (DPO)]}

Days Inventory Outstanding (DIO) is a key figure that measures the average amount of time that a firm holds its inventory. It is calculated by inventory/cost of sales x 365 days. A decrease in the DIO represents an improvement, an increase in deterioration. Days Sales Outstanding (DSO) is the key figure that measures the average amount of time that a firm holds its account receivables. Its formula to calculate is account receivables/sales x 365days. A decrease in DSO represents an improvement, whereas an increase represents deterioration. Days Payables Outstanding (DPO) is the key figure that measures the average amount of time that a firm holds its trade payables. It is calculated by trade payable/cost of sales x 365days. For DPO, an increase in days represents an improvement, whereas a decrease indicates deterioration (Francis, 2017)

The traditional view on Cash Conversion Cycle (CCC) and profitability highlights that the shorter the CCC, the superior the firm profitability. The firm can shorten its CCC by improving the inventory turnover, collects cash from receivables more quickly, and slowing down the payments to suppliers. This will increase the efficiency of the firm internal operation and result in greater profitability. On the other hand, shortening the Cash Conversion Cycle (CCC) could harm the firm's profitability as reducing the inventory conversion period could increase the shortage cost, reducing the receivable collection periods could make the company's losing its good credit customers, and lengthening the payable period could damage the firm's credit reputation. Therefore, shorter cash conversion cycles associated with high opportunity cost, and longer cash conversion cycles associated with high carrying cost (Francis, 2017). Are there adequate systems to monitor, measure and manage the daily collection and disbursement of cash and the daily investment of cash? Is the system of internal controls over cash collection and disbursements, cash investments and liquid assets assessed periodically to ensure it is effective. 


\subsubsection{Code of Governance for state Corporations}

Recently, the GOK has put great emphasis on Risk management. In January 2015, PSC issued 'MWONGOZO' the code of governance for State Corporations which directs the Board of each SC to ensure that it set out its responsibility for risk management in the Board charter, approve the risk management policy and the risk management framework, delegate to management the responsibility to implement the risk management plan, monitor that risks taken are within the set tolerance and appetite levels, review the implementation of the risk management framework on a quarterly basis, appoint a Committee responsible for risk management in the organization, ensure that the Committee obtains relevant technical advice where necessary, evaluate the performance of the Committee once a year, establish a risk management function within the organization, ensure that risk assessment is carried out on a continuous basis and receive assurance from Management that the risk management framework is integrated in the daily activities of the organization.

\subsubsection{Financial Performance}

Performance is important in implementing the set objectives into outcomes and desired results. All institutions and organizations across the world, work hard to ensure they improve their performance by adopting measures and practices. In the business sector, performance is measured using financial elements, effectiveness in resource utilization and efficient processes that add value to the organization. Many people often assume that high performance is all about the profitability of an enterprise, but performance is examined and evaluated specifically to the type of business organization, philosophies adopted, management thinking, organizational mission and the prevailing environmental conditions and other numerous factors (Van-Doreen et al., 2016).

The key indicators and measures of financial performance of the firm include returns on assets, equities and investments, sales turnover and gross margin. On the other hand, non-financial measures include customer satisfaction and learning. A measure of organizational performance can be established through comparison of performance across different horizons and periods in addition to performance of other firms. However, there is no unique measure of performance capturing all aspects of performance and this limit applicability of one measure (Epstein et al., 2015).

Elly (2012) in his study on executive compensation and firm performance suggests that various stakeholders of any organization influence how its performance is measured and communicated. The study reiterates that despite the numerous performance measures in place, there has been no accord on a unanimously acceptance performance measure. It also noted that various stakeholders have varying information and expectations depending on the measure adopted and therefore deep consideration is needed for the performance measure adopted.

The performance of State Corporation is portrayed by the levels of asset base, revenue growth and level of customer satisfaction (Adhiambo and Memba, 2012). Most state corporations target increased profits, liquidity and solvency as a measure of their sound financial health. Liquidity measures the ability to meet financial obligations as they come due without financial obligations and without disrupting the normal ongoing operations of State Corporations while solvency 
measures the amount of borrowed capital used by the institution relative to the amount of owner's equity capital invested in business.

Four useful measures of firm Profitability are the rate of return on assets (ROA), the rate of return on equity (ROE), operating profit margin and net firm income. The return on assets ratio also called the return on investment ratio (ROI) is a profitability measure that evaluates the performance of a business or investment, or the potential return from a business or investment, by dividing net profit by net worth, with the result expressed as a ratio or percentage (Peavler, 2018).

ROA is computed by dividing the Net income by the Total Assets. Total assets represent the ability of the firm to generate revenue and therefore profitability. According to Kharwish (2011) the ability of a firm to access finance leads to better financial performance. ROA (Net Income $\div$ Average Assets) show how efficiently and effectively the management of a firm is able to generate income from resources of the institution.

Return on equity (ROE) reveals how much after-tax profit a company earned in comparison to the total amount of shareholder equity found on the balance sheet (Return on Equity $=$ Net Profit $\div$ Average Shareholder Equity for Period). Shareholder equity is equal to total assets minus total liabilities (Kennon, 2017). In linking Liquidity Risk management and Financial Performance for SOEs, the mean scores of each liquidity risk management indicator will be correlated with the ROA. Governments run with tight budgets, hence there is an increasing demand to re-examine their spending priorities, the financial reporting system should cut out misappropriation of funds and inefficiencies in the operating systems.

\subsubsection{State Owned Enterprises in Kenya}

State Owned Enterprises (SOEs) in African countries have been in existence since early 1950s and continued to grow in the sub-Saharan Africa by the 1980s. They are however, associated with history of continued poor performance (Mbo, 2017). Rising expectations by the taxpayers have influenced Governments and have forced them to reform the corporate governance systems and practices in state owned enterprises, so as to improve their operations hence improved performance.

State owned enterprises emerged in Kenya with the colonial Government and were to provide services which the private sector couldn't provide (Franklin, 2018). The areas or sectors included export of agricultural produce, communication and transportation, manufacturing and agricultural trade facilitation. They are formed through an act of parliament, section 2 of the state corporation Act, a legal notice or through the normal State-Owned Enterprises Act Cap 486. These state-owned Enterprises have however, been performing poor financially leading to constant bail-out by the Government (Mihyo and Mukuna, 2018). Despite the Government bailout some of the State Owned Enterprises do not perform well while others perform well after the bail-out.

In Kenya, state corporations are formed to meet social and commercial objectives. Such corporations exist for a number of reasons, for example, as instruments used to correct market failure, to supply basic services such as health and education, to increase development in marginalized areas, and to achieve political objectives. State owned enterprises can be fully owned or partially owned by government. Examples of such entities in Kenya include, Kenya 
Power and Lighting Company, Kenya Pipeline Company Limited and the Kenya Ports Authority among others (National Treasury, 2018).

The functions of a specific state owned enterprise will be dictated by the constitutive instrument such as the memorandum and articles of association for the entities that are limited liability companies, the various statutes for the statutory state corporations the order which is specific to it for those that are created by way of an executive order (Shaheer et al., 2017).

Another important characteristic of these corporations is that the entities and their employees are subject to a specific legal framework that binds public entities and public servants. The main limitation of this is that such a legal framework has the effect of subjecting these enterprises, their Boards, managers and employees to extra and more stringent quality controls by both government authorities and investors (Gitundu et al., 2016).

The main goal of an enterprise is to perform a commercial role. The most basic objectives of any business would be to create wealth by increasing its profitability by either increasing production or minimization of operating costs or both. Minimizing costs and maximizing profits, is, in summary, the main aim of doing business (Nyamita et al., 2015). Commercial state corporations also serve a governance role. They are deemed to be an extension of the Executive and as such their employees are public servants and they will be subjected to all the governance structures and statutes that relate to the public service. This dual role cannot be overlooked (Mbo, 2017).

Some of the problems faced by state owned corporations stem mainly from political interests which usually results in the mismanagement of assets of the commercial state-owned corporations. The reason for political influence in appointments of Chief Executives and their boards is that such politicians are in most cases aiming at controlling commercial state-owned corporations for political reasons. This leads to poor performance of SOEs, corruption and misappropriation of public funds (Mohamed, 2013).

\subsubsection{Financial Performance of State Owned Enterprises in Kenya}

The amount of money being absorbed by the SOEs from the exchequer far surpasses the tax revenue gained from them. Capital grants to SOEs have increased by almost $120 \%$ in the last four years, rising from Kshs 169 billion in the 2013/14 FY to Kshs 414 billion in 2016/17 and about Kshs 345 billion in 2017/18. This has been a HUGE increase and to put it into perspective this ranges from between 5-6\% of annual GDP just on capital grants. The pressure of SOEs levied on the budget is evident if they are absorbing so much capital but not creating the requisite economic value for a net gain to the country. State owned enterprises take upto 6\% GDP trough capital grants. Often such investments do not bear financial returns leaving a hole in the Budget which is filled by tax payer ((Kenya Business Guide, 2019).

The corporate world faces a lot of risks and hence for improved financial performance, there is need to have in place sound and effective risk management. Alshatti (2015) showed that risk management is not applicable in the commercial sector but can apply even in government setting and any other sector of the economy. This is due to the fact, that all organizations need resources for delivery of products and services. The resources are limited in supply and hence the need for proper management to attain set objectives. 
Public entities, including state corporations, are today under more pressure than ever to manage costs and deliver services more efficiently. As operating budgets are scrutinized, public officials search for creative means of cutting costs, maximizing the productivity of existing staff, and working smarter to serve the public's interests. In order to fulfill their purpose, many public organizations have crafted strategies to guide them in the competitive environment in which they operate. Pursuing such strategies comes with risk. Management of such risks is a key driver in capturing the potential gains (Kaplan and Mikes, 2012).

\subsection{Statement of the Problem}

The amount of money being absorbed by the SOEs from the exchequer far surpasses the tax revenue gained from them. Capital grants to SOEs have increased by almost $120 \%$ in the last four years, rising from Kshs 169 billion in the 2013/14 FY to Kshs. 414 billion in 2016/17 and about Kshs 345 billion in 2017/18. This has been a HUGE increase and to put it into perspective this ranges from between 5-6\% of annual GDP just on capital grants. The pressure of SOEs levied on the budget is evident if they are absorbing so much capital but not creating the requisite economic value for a net gain to the country. State owned enterprises take upto 6\% GDP trough capital grants. Often such investments do not bear financial returns leaving a hole in the Budget which is filled by tax payer (Kenya Business Guide, 2019).

As argued by Eljelly (2004), managing liquidity is important when firms are in a good situation, but is most important during troubled times of firms' performance. When a firm is unable to pay its obligations, it is illiquid. Furthermore, aggressive liquidity management is associated with higher corporate value, despite differences in structural characteristics or in the financial system of a firm. Liquidity management is important for all firms in all situations.

A number of studies have been conducted on Liquidity risk management and financial performance of companies in Kenya but little has been studied on state owned enterprises. There is inadequate literature linking liquidity risk management to financial performance of state owned enterprises in Kenya. The scarcity of available, reliable and valid data continues to be one of the key obstacles in understanding the effect of liquidity risk management on financial performance of state owned enterprises in Kenya.

There exists a knowledge gap which this study aims to fill by exploring liquidity risk management and financial performance of Kenyan commercial state Corporations. Such analysis is hardly available and the outcome of the study forms a basis on liquidity risk management by state owned enterprises in Kenya and also would fill in on the existing knowledge gap that such state Corporations could leverage on to improve financial performance. This study therefore seeks to investigate the effect of liquidity Risk Management on financial performance of state owned enterprises in Kenya.

\subsection{Theoretical Review}

\section{Decision Theory}

The first general theory of the stages of a decision process was put forward by the great enlightenment philosopher Condorcet (1743-1794) as part of his motivation for the French constitution of 1793(Hansson, 1994).Decision theory is theory about decisions. Modern decision theory has developed since the middle of the 20th century through contributions from several 
academic disciplines (Hansson, 2005).Normative and descriptive theories makes up the decision theory. The distinction between normative and descriptive decision theories is, in principle, very simple. A normative decision theory is a theory about how decisions should be made, and a descriptive theory is a theory about how decisions are actually made (Hansson, 2005).

Decision theory is concerned with calculating the consequences of uncertain decisions. As risk management is concerned with making decisions to manage uncertainties and their consequences and decision theory is concerned with looking at choices people make, it would seem that these two disciplines share a common ground and are often used jointly. However the only part of decision theory that is applied to risk management is calculating the expected value of a risk, while other aspects of decision theory are seldom used (Hansson, 2005).Risk appetite allows for a consistent approach to handling risks within an organization. Another term associated with this is risk attitude which can be elicited from the upper echelon of an organization and thus expressed in a quantitative manner by use of risk appetite which reflects risk taking behavior (Pennings and Smidts, 2000).

An agent's risk attitude can be elicited relatively in a straightforward way. When an agent is offered a choice between a risky and a safe option, the agent chooses and their preference is found. Depending on the choice the agent made, the sure option is made more or less attractive after which the agent makes their choice again. This process can be repeated several times to iterate towards a point where both options are equally attractive and thus a point of indifference is reached. Such methods of eliciting risk attitude have been successfully used in experiment (Pennings and Smidts, 2000).Risk management makes decisions to manage uncertainties while decision theory can prescribe what the correct course of action would be to deal with the uncertainty. The theory is relevant to our study as it encourages hypothetical thinking that are concerned with calculating the consequences of uncertain decisions made by the firm.

The critique of decision theory includes the environment in which natural decisions take place which is considerable different from those in which experimental decisions are made. Much of Decision theory Literature uses models of human thought processes that exceed actual human capabilities. (FJellman, 1976). 


\subsection{Conceptual Framework}

The conceptual framework looked at the effects of liquidity risk management on financial performance of state owned enterprises and it is illustrated in Figure 1

Independent variables

Dependent

Variable
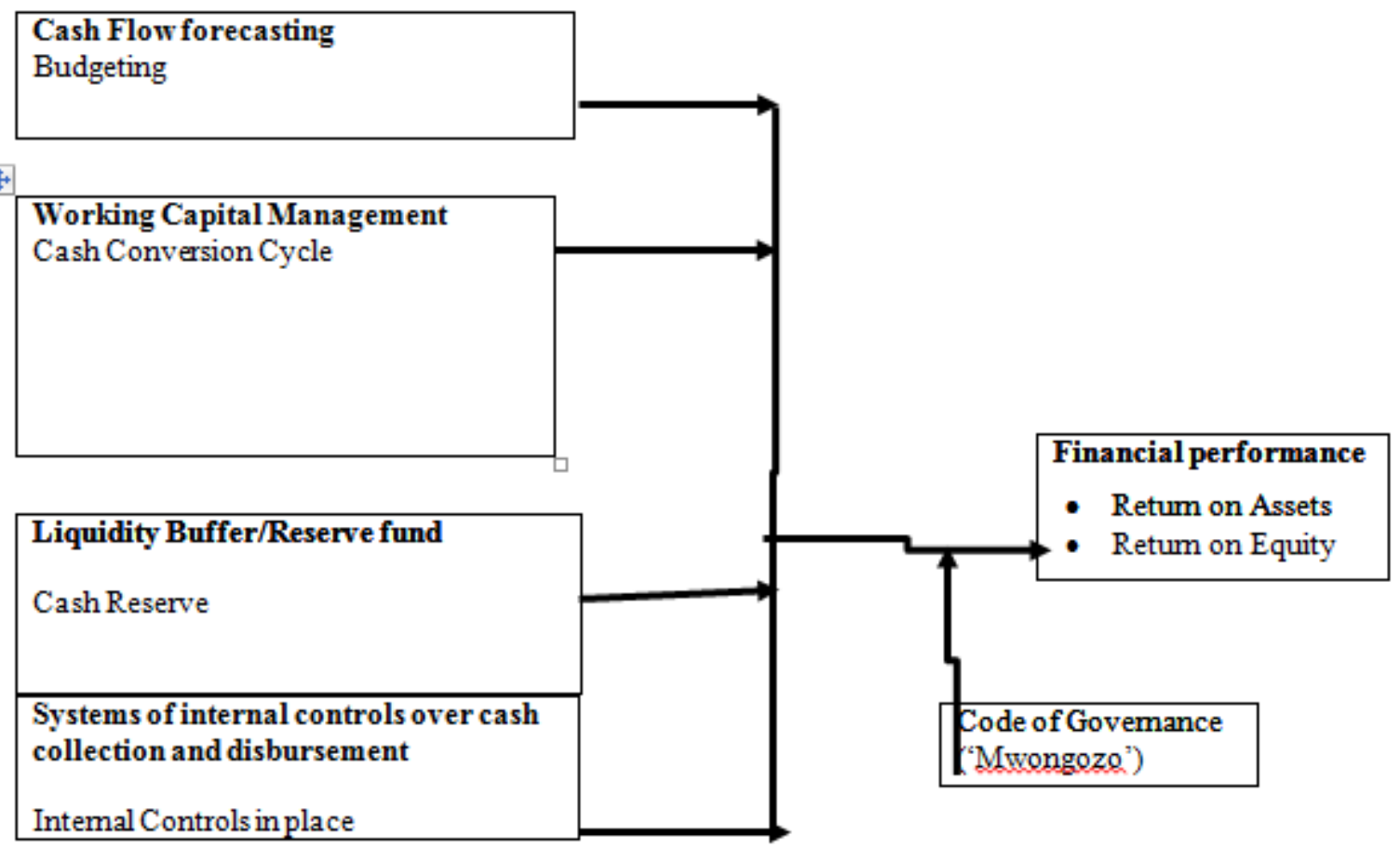

Figure 1: Conceptual Framework

\section{METHODOLOGY}

The study adopted a desktop methodology. Desk research refers to secondary data or that which can be collected without fieldwork. Desk research is basically involved in collecting data from existing resources hence it is often considered a low cost technique as compared to field research, as the main cost is involved in executive's time, telephone charges and directories. Thus, the study relied on already published studies, reports and statistics. This secondary data was easily accessed through the online journals and library.

\subsection{RESULTS}

The results were grouped into various research gap categories namely as conceptual, methodological, contextual, and geographical.

\subsection{Conceptual Gaps}

Studies by Ariffin (2012); Waswa, Mukras \& Oima (2018); Mwambui and Koori (2019); Pimpong and Laryea (2016); Madugba and Ogbonnaya (2016); Djumahir and Roni (2016); 
Hamza and Mutala (2015); Oluoch (2016); Dzapasi(2020) had conceptual framework gap. In addition all the mentioned studies did not establish the effect of liquidity Risk Management on financial performance of state owned enterprises in Kenya. The studies did not outline the relationship between independent and dependent variable in a clear manner. Therefore the current study seeks to address these conceptual gaps.

\subsection{Contextual and Geographical Gap.}

Studies by Ariffin (2012); Chowdhury and Zaman (2018); Pimpong and Laryea (2016); Mohamed and Ali (2013); Madugba and Ogbonnaya (2016); Djumahir and Roni (2016); Hamza and Mutala (2015); Dzapasi(2020); Dimitropoulos and Koronios (2019) had geographical gap because they were not conducted in Kenya. This implies that the results may be inapplicable in Kenya since the social economic environment of Kenya and other countries differ. The current study seeks to address this gap.

\subsection{Methodological Gap}

Studies by Ariffin (2012); Waswa, Mukras \& Oima (2018); Mwambui and Koori (2019); Pimpong and Laryea (2016); Madugba and Ogbonnaya (2016); Djumahir and Roni (2016); Hamza and Mutala (2015); Oluoch (2016) had different time scope. The current study seeks to cover to upto 2021

\section{CONCLUSIONS AND RECOMMENDATIONS}

The study will be significant to state owned enterprises, students, general public and State Corporations Advisory Committee as it will offer contributions from both a theoretical and practical perspective.

Regulatory bodies such as SCAC as well as the government can utilize the findings from the study to improve on the framework for policy formulation and regulation. The study will be helpful in safeguarding the resources of the country. Theoretically; it will contribute to the general understanding of liquidity risk management practices and their effect on financial performance.

The study will be important to Commercial and manufacturing state Corporations as it will help them to improve their risk management process and to adopt efficient strategies to improve financial performance through risk management process. This will enable the state corporations to perform better. Theoretically, it will contribute to the general understanding of liquidity risk management practices and their effect on financial performance.

The general public will benefit from the study through improved services they will get from the state corporations. The study will create awareness on the concept of liquidity Risk management and the role they can play in adoption and implementation of best practices. Theoretically, it will contribute to the general understanding of liquidity risk management and their effect on financial performance.

The study will add to the existing body of knowledge on liquidity risk management to benefit academicians and aid further study on liquidity management in the same sector. The study will be of great importance to researchers as they will gain from both theoretical and empirical literature. 
International Journal of Finance and Accounting

ISSN 2513-4311X (online)

Vol.6 Issue 2, No.2. pp. 12 - 28, 2021

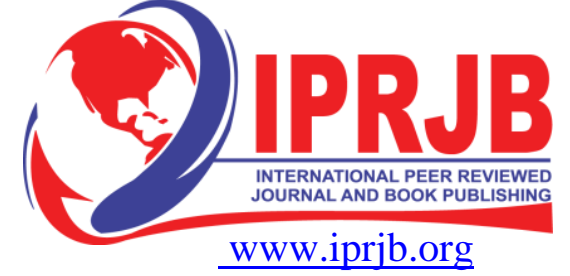

\section{REFERENCES}

Abeywardena,I.S., Raviraja, S., \&Tham, C.Y. (2012). Conceptual framework for parametrically measuring the desirability of open educational resources using D-index.The International Review of Research in open and Distributed Learning, 13(2), 59-76.Retreaved from http://www.irrodl.org/index.php/irrodl/article/view/1177/2142

Adamov, E.O.,Dzhalavyan, A.V., Lopatkin, A.V., Molokanov,N.A., Muravyov,E.V., Orlov, V.V., \&Ivanon, V.B. (2012).Conceptual framework of a strategy for development ofnuclear power in Russia to 2100.Atomic Energy, 112(6), 391-403.Retrieved from https://link.springer.com/ article/10.1007/s10512-012-9574-X

Adhiambo, A. A., \&Memba, M. S. (2012). Credit Cards and Performance of Commercial Banks Portfolio in Kenya.International Journal of Arts and Commerce,1(6): 167-173.Retrieved from https://www.ijac.org.uk/images/ frontImages/gallery/Vol.1_No.6/18.pdf

Alshatti, A. S. (2015). The effect of credit risk management on financial Performance of the Jordanian commercial banks. Investment Management and Financial Innovations, 12(1), 338-345.

Ariffin, N. M. (2012). Liquidity risk management and financial performance. Aceh International Journal of Social Sciences, 1(2): 68-75.

Barton, T. L., Shenkir, W. G., \& Walker, P. L. (2002). Making Enterprise Risk Management Pay Off: How Leading Companies Implement Risk Management, Financial Upper Saddle Times/Prentice Hall,River, NJ.

CPA ustralia (2010). Guide to Managing Liquidity Risk, ISBN 978-1-921742-00-2. Retrieve from https:/www.bing.com/search?q=Guide+to+managing+liquidity+Risk+cpa+ Australia+ISBN+978-1-921742-00-

$2+\& \mathrm{qs}=\mathrm{n} \&$ form $=\mathrm{QBRE} \& \mathrm{sp}=1 \& \mathrm{pq}=$ guide+to+managing+ liquidity $\quad+$ risk $+\& \mathrm{sc}=0$ 33\&sk=\&cvid=69BC701E66FF4DFD94E8F121A4C3ED99 on 10th September 2021.

Dejin, L. (2020). The impact of Liquidity management on profitability in Chinese Big Four state owned Commercial Banks. Retrieved from The impact of liquidity management on profitability in Chinese Big Four State-Owned commercial banks | WIRE - WenzhouKean University Intellectual Research Environment (wku.edu.cn)

Dimitropoulos P and Koronios K. (2019): Cash holdings, corporate performance and viability of Greek SMEs Implications for stakeholders. The current issue and full text archive of this journal is available on Emerald Insight at: www.emeraldinsight.com/1450-2194.htm.

Djumahir A.D and Roni H. (2016): The Effect of Working Capital Management on Profitability of State-Owned Enterprise in Processing Industry Sector. Journal of Applied Management (JAM) Volume 16 Number 2, June 2018 Indexed in Google Scholar

Dzapasi F. D (2020) : The impact of Liquidity Management on Bank Financial Performance in a subdued economic environment: A case of the Zimbabwean Banking Industry. PM World Journal (ISSN: 2330-4480) The impact of Liquidity Management on Vol. IX, Issue I January 2020 Bank Financial Performance www.pmworldjournal.com Featured Paper by Farai D. Dzapasi 
Eleftheriadis, I. \&Vyattas, V. (2018).Risk and performance in Public Sector.10. 1007/978-3319-31816-5_3453-1

Eljelly, A. M., (2004). Liquidity-profitability tradeoff: an empirical investigation in an emerging market. International Journal of Commerce and Management, 14(2), 48-61.

Elloumi, F., \& Gueyie, J. (2001). Liquidity and corporate governance: an empirical analysis. Corporate Governance. International Journal of Business in Society, 1(1), 15 - 13.

Elly, D.O. (2012).Executive compensation and Firm Financial performance. A critical Literature Review. Retrieved from http://hdl.handle.net/11295/39259

Enya, E.F. and Effong, D.A. (2020). Liquidity Risk management and Financial Performance :Are consumer Goods campanies involved? International Journal of Recent Technology and Engineering (IJRTE) ISSN: 2277-3878, Volume-9 Issue-1, May 2020

Epstein, M. J., Buhovac, A. R., \& Yuthas, K. (2015). Managing social, environmental and financial performance simultaneously. Long Range Planning, 48(1), 35-45.

Fabozzi, F.J., Gupta,F. \& Markowitz, H.M. (2003). The legacy of Modern portfolio theory.Journal of investing.Vol.11 (3) 7 - 22. https://doi.org/10.2469/dig.v33.n2.1273

FJellman, S.M. (1976). Natural and unnatural Decision making.A critique of decision theory. Retrieved from onlinelibrary.wiley.com/doi/10.1525/eth.1976.4.1.02a00040/pdf

Francis A. (2017): Financial Management. Retrieved from Financial Management Archives - Page 3 of 49 - MBA Knowledge Base (mbaknol.com)

Franklin, A. (2018). Corruption and Contracts with States or State Owned Enterprises: Effects on Enforcement of the Contract in Arbitration Decisions.

Gitundu, E. W., Kisaka, S. E., Kiprop, S. K., \& Kibet, L. K. (2016). The Effects of Ownership and Corporate Governance Reforms on Efficiency of Privatized Companies in Kenya. International Journal of Economics and Financial Issues, 6(1), 323-331.

Gossy, G. (2008). A Stakeholder Rationale for Risk Management: Implications for Corporate Finance Decisions.Retrieved from https://books.google.co.ke/ books/about/A _Stakeholder_Rationale_for_Risk_Managem.html?id=dsxsHS9cJMQC\&redir_esc=y

Haczynski, T. (2015). Asset and Management. Banking Book-Risk. Global Association for Risk Professionals. Rtrieved from RMA / Wharton Executive Education Program Liquidity Risk Philadelphia, PA (garp.org)

Kenya Business Guide (2019). Privatize or Die? Restructuring state owned Enterprises for Economic growth. Retrieved from 'Privatize or Die?' Restructuring State-Owned Enterprises for Economic Growth - Kenya Business Guide on 5th September 2021.

Halling, M., \& Hayden, E. (2006). Institution failure prediction: a two-step Survival time approach, C.R.E.D.I.T. Conference. Austrian National institution Vienna, 101 - 109

Hamza K. and Mutala Z. (2015): Cash Management Practices and Financial Performance of Small and Medium Enterprises (SMES) in the Northern region of Ghana. International Journal of Economics, Commerce and Management United Kingdom Vol. III, Issue 7, 
July 2015 Licensed under Creative Common Page 456 http://ijecm.co.uk/ ISSN 2348 0386

Hansson, S.O.(1994).Decision theory.A brief introduction.Retrieved from http://www2. cs.siu.edu/ hexmoor/classes/CS539-F10/DT.pdf

Hansson, S.O (2005).Decision theory. A brief introduction .Royal institute technology; Stockholm. Retrieved from https://www.researchgate.net/publication/210642121 _Decision_Theory_A_Brief_Introduction

Heath, J. (2009). The uses and abuses of Agency Theory. Retrieved from http://citeseerx.ist.psu.edu/viewdoc/download?doi=10.1.1.336.2417\&rep=rep1\&type=pdf

IFCM.(n.d). Limitations of Modern Portfolio Theory.Retrieved July 20, 2021 from / https://www.ifcm.capital/modern-portfolio-theory/limitations-of-modern-portfoliotheory-mpt

Jeanne, O., \& Svensson, L. O. (2007). Credible commitment to optimal escape from a liquidity trap: the role of the balance sheet. The American Economic Review, 97(1), 474-490.

Kaplan, R.S. \& Mikes, A. (2012).Managing Risks;A new framework. Retrieved from https://hbr.org/2012/06/managing-risks-a-new-framework

Kennon, J. (2017, November 6) Return on Equity and income statement analysis. Retrieved from https://www.thebalance.com/return-on-equity-roe-357601

Khrawish, H.A (2011).Determinants of Commercial Bank performance .Evidence from Jordan. International Research Journal of Finance and Economies.Zarga University 5(5) 19 - 4

Krause, T.A, Tse, Y. (2016). Risk Management and firm value: Recent theory and Evidence. International Journal of Accounting and information management, 24(1); 56 81.www.emeraldinsight.com/1834-7649.htm

Laryea H. and Pimpong S. (2016) BUDGETING AND ITS IMPACT ON FINANCIAL PERFORMANCE: THE CASE OF NON-BANK FINANCIAL INSTITUTIONS IN GHANA. International Journal of Academic Research and Reflection Vol. 4, No. 5, 2016 ISSN 2309-0405

Madugba J.U and Ogbonnaya A.K (2016): working capital management and Financial performance: Evidence from manufacturing companies in Nigeria. European Journal of Accounting, Auditing and Finance Research Vol.4, No.9, pp.98-106, August 2016

Mandelbrot, B., \& Hudson, R. L. (2004), The (Mis) Behaviour of Markets: A Fractal View of Risk, Ruin, and Reward, London: Profile Books.

Markowitz, H. (1952). Portfolio Selection, Journal of Finance 7 (1), 77-91. http://www.jstor.org/about/terms.html

Maness, T. S., \& Zietlow, J. T. (2005). Short-term Financial Management. South Western/Thomson Learning, Ohio.

Mbo, M. (2017). Drivers of organizational performance: a state owned enterprise perspective (Doctoral dissertation, Stellenbosch: Stellenbosch University). 
Mihyo, P. B., \& Mukuna, T. E. (2018). Interface between Formal and Informal Systems of Horizontal Accountability in Kenya's State-Owned Enterprises. Eastern Africa Social Science Research Review, 34(2), 101-131.

Modigliani, F. \& Miller, M.H. (1958). The Cost of Capital, Corporate Finance and the Theory of Investment, American Economic Survey, 48(3) 261-297.http://www.jstor.org/stable/ 1809766? origin=JSTOR-pdf

Mohamed A.I and Ali A.Y.S (2013) Relationship between budgeting and Performance of remittance Companies in Somalia.

Mozumdar, A. (2001). Corporate Hedging and Speculative Incentives: Implications for

Swap Market Default Risk. Journal of Financial and Quantitative Analysis, 36(2), 221250.https://doi.org/10.2307/2676272

Mugenda, O.M., \&Mugenda, A.G. (2012).Research methods dictionary.Retrieved from http://irlibrary.ku.ac.ke/handle/123456789/8329

Muriithi,J.N., and Waweru, K.M.(2017). Liquidity Risk and Financial Performance Of Commercial Banks in Kenya, International Journal of Economics and Finance; Vol. 9, No. 3; 2017 ISSN 1916-971X E-ISSN 1916-9728 Published by Canadian Center of Science and Education. https://doi.org/10.5539/ijef.v9n3p256

Muriungi, C. N., Waithaka, M., Were, E., \& Muriuki, M. (2017). Effects of risk Management on financial stability of state corporations in Kenya: A survey of Tourism Fund (TF) and Kenyatta International Convention Centre (KICC). International Academic Journal of Economics and Finance, 2(3), 268-291

Oluoch J.O (2016): The Impact of Cash Management Practices on Performance of SMEs: A Survey of SMEs in Eldoret Central Business District. IOSR Journal of Economics and Finance (IOSR-JEF) e-ISSN: 2321-5933, p-ISSN: 2321-5925.Volume 7, Issue 6 Ver. III (Nov. - Dec. 2016), PP 01-07 www.iosrjournals.org

Olsson, R. (2008). Risk Management in a Multi-Project Environment: An Approach to Manage Portfolio Risks.International Journal of Quality \& Reliability Management, 25 (1), 6071. https://doi.org/10.1108/02656710810843586

Omasate, C.A. (2014). The effect of Risk Management on Financial performance of Insurance Companies in Kenya. Retrieved from http://hdl.handle.net/11295/74732

Osoro , E.M. and Muturi, w.(2015). Effects of Liquidity Risk Management practices on Financial performance of Savings and Credit Cooperative societies in Kisii County. International Academic Journal of Information Sciences and Project Management | Volume 1, Issue 4, pp. 68-85. Available Online at: http://www.iajournals.org/articles/iajispm_v1_i4_68_85.pdf

Peavler, R.(2018, May 20). The return on investment Ratio explained. Retrieved from https://www.thebalance.com/return-on-investment-ratio-393206

Pennings, J.M. \&Smidts, A.(2000).Assessing the construct validity of risk attitude. Management Science,46(10),1337 - 1348.Retrieved from https://pubsonline.informs. org/doi/pdf/10. 1287/mnsc.46.10.1337.12275 
Podilchuk, Z. (2013). Impact of Liquidity Management on Profitability: Evidence from Ukraine. (MA), Ukraine.

Regoniel, P.A. (2015). Conceptual Framework.A step by step guide on How to make one. Retrieved from http:simplyeducate.me/2015/01/05/Conceptual-framework-guide

Richards, V. \& Laughlin, E. (1980). A Cash Conversion Cycle Approach to Liquidity Analysis, Financial Management, 9(1), 32-38, ISSN 0046-3892

Samiloglu, F., \& Demirgunes, K. (2008). The Effect of Working Capital Management on Firm Profitability: Evidence from Turkey. The International Journal of Applied Economics and Finance, 2, 44-50.

Shaheer, N., Yi, J., Li, S., \& Chen, L. (2017). State-Owned Enterprises as Bribe Payers: The Role of Institutional Environment. Journal of Business Ethics, 1-18.The National Treasury and planning (2021): Update on reforms of state

Corporations. Republic of Kenya; press statement. Retrieved from Press-Statement-8th-July2021-Update-on-Reforms-of-State-Corporations.pdf (treasury.go.ke)

The National Treasury (2018). State-owned corporations. Retrieved from http://treasury.go.ke/27- about-us/168-state-corporations

Terseer,W.,Henry, Y., and Mkuma, Y.P.(2020). Effect of Liquidity management on the Financial Performance of Banks in Nigeria. European Journal of Business and Innovation Research Vol.8, No.4.pp. 30-44, July 2020 Published by ECRTD-UK Print ISSN: 20534019(Print), Online ISSN: 2053-4027(Online)

Van Dooren, W., \& Van de Walle, S. (Eds.). (2016). Performance information in the public sector: How it is used. Springer.

Verma, E.(2021). Financial performance: Understanding the Concept and its Areas. Retrieved from Financial Performance: Understanding The Concepts And Its Areas (simplilearn.com) on 22nd September 2021.

Wani, A.A and Dar, S.A. (2015). Relationship between Financial Risk and Financial performance: An insight of Indian insurance industry, nternational Journal of Science and Research (IJSR) ISSN (Online): 2319-7064 Index Copernicus Value (2013): 6.14 | Impact Factor (2014): 5.611. http://www.ijsr.net/ 